\title{
SWOT Analysis of Pakistan Education System: Impact of China- Pakistan Economic Corridor
}

\author{
Sabika Khalid ${ }^{1}$, Endale Tadesse ${ }^{2}$, Wang Muhua ${ }^{3}$, Deng Lei ${ }^{4}$ \\ ${ }^{1}$ Faculty of Education, Southwest University, China \\ ${ }^{2}$ Faculty of Education, Southwest University, China \\ ${ }^{3}$ Professor, Faculty of Education, Southwest University, China \\ ${ }^{4}$ Professor, Faculty of Education, Southwest University, China
}

\begin{tabular}{|c|c|}
\hline Article Info & Abstract \\
\hline Article history: & Purpose: The aim of the study is to review the impact of China-Pakistan \\
\hline & Economic Corridor on the Pakistani educational sector. Furthermore, the \\
\hline & tudy critically examines the present educational challenges of the Pakistan \\
\hline Acce & $\begin{array}{l}\text { education system and CPEC logistics arrangement between China and } \\
\text { Pakistan. }\end{array}$ \\
\hline Key & Approach/Methodology/Design: We analyzed literature through SWOT \\
\hline $\begin{array}{l}\text { Educ } \\
\text { Chin }\end{array}$ & $\begin{array}{l}\text { analysis to review the strengths, weaknesses, opportunities, and threats in } \\
\text { the context of education. }\end{array}$ \\
\hline r (CPEC), & Findings: The analysis indicated that CPEC not only benefits the economy \\
\hline SW & $\begin{array}{l}\text { and bilateral trade between the two countries but it also offers opportunity } \\
\text { for Pakistan to adopt and access more policies to strengthen the educational } \\
\text { sector of the country. The SWOT analysis also demonstrates that CPEC has } \\
\text { more venues of opportunity rather than threats. }\end{array}$ \\
\hline Pape & Practical Implications: The study offers an overview of CPEC effect on \\
\hline & $\begin{array}{l}\text { education in Pakistan. Though it is mainly economy-driven, this study } \\
\text { analyzes the CPEC with a focus on the effects on the educational system in }\end{array}$ \\
\hline Corresponding Author: & $\begin{array}{l}\text { Pakistan. This opens a venue for more engagement between the two } \\
\text { countries in terms of training, academic exchange, and educational }\end{array}$ \\
\hline Sabika Khalid & $\begin{array}{l}\text { planning. } \\
\text { Originality/value: This study examines the effects of CPEC on the education }\end{array}$ \\
\hline $\begin{array}{l}\text { Email: } \\
\text { sabikakhalid42@gmail.com }\end{array}$ & $\begin{array}{l}\text { system in Pakistan. Most of the literature on CPEC is concerned about the } \\
\text { economic effect. This study investigates how CPEC impacts the educational } \\
\text { aspects in Pakistan. }\end{array}$ \\
\hline
\end{tabular}

\section{Introduction}

Countries are promoting and supporting open society to evaluate globalization, the Silk Road from the ancient camels' bells jingling to all the new way of globalization and economic advancement around the globe. It is the evidence of the Chinese government's vision and lead of globalization. China strengthens its relations with Euro-Asian countries regards "as one of its most important strategic partners" (EC, 2018a). The initiative is not only driving force for China, it is eventually an opening of opportunities for all linked countries.

Over the years, Pakistan-China perennial ties of profound friendship got boost with 
the CPEC. China's dream for globalization, unveiled in 2013 with the title of One Belt One Road (OBOR) and New Silk Road (NSR), has the historical connections with ancient camels' jingling bells and mist of trades that rise with the mega-project connecting almost 60 countries around the world, with enormous investment with the objective of mutual perspectives of trade and efficient development.

In this regional incorporation, Pakistan is a fundamental player. China-Pakistan Economic Corridor (CPEC) is a game-changer opportunity for Pakistan; regionally status and modern technological network are the fortuity to Pakistan to avail of these benefits (Shapiee \& Idress, 2017). However, the strategic realms of the Silk Road initiative were proposed by the Xi Jinping government with the fundamental foreign economic policy with several economic, political, cultural benefits to the whole region. The initiative has become the centre of attention for policymakers and researchers; the number of studies highlighted the direct and indirect impact of this initiative on Pakistan. Most of the studies recognize the economic or direct influence of Silk Road on Pakistan in particular. Khan (2015) argued that it will create job opportunities for a lower class; trade logistic (Vickerman, 2002); boost Pakistan economic status in the region (Maher, Hussain, \& Ahmad, 2014; Mateen, 2015; Zafer, 2015; Muhammad, Qi, \& Hamza, 2016).

However, all these factors of New Silk Road will have also an effect on the education sector. The project (Silk Road or One Belt One Road) connects the Euro-Asian continents, and also integrates higher education on new and different conditions (Kirby \& Wende, 2018). Hence, the paradoxical impact of China's New Silk Road is a centre of attention for scholars due to multiple aspects of policy and the large extent of a project; the historically land-based trading routes connecting the old trades paths to soft power academic concepts (Albert, 2018; Kirby and Wende, 2018). Hence, the present study analyzed the impact of CPEC or B\&R impact on the Pakistan Education system. The economic effect of CPEC is well-recognized, but the effect on educational systems is still not examined. This study is an attempt to unravel the impact of CPEC on the educational aspects.

\section{Literature Review}

\section{Pakistan Education System}

Throughout the globe, the developing economies are struggling for the better progression and advancement of the education sector for rational economic growth and substantial development. In poverty sicken array Pakistan and the Ministry of Education (MOE) are reinvigorate policies to meet the educational challenges in the country. Although, according to ( Article 25-A), "the State shall provide free and compulsory education to all children of the age of five to sixteen years in such a manner as may be determined by law"( Constitution of the Islamic Republic of Pakistan, 1973, p.15). However, looming educational obstacles the Constitution also emphasizes the need for education. Likewise, the articles state "that the country is responsible for providing necessities of life, such as food, clothing, housing, education, and medical relief, for all citizens, irrespective of sex, caste, creed or race,"(p.19) 
... "to remove illiteracy and provide free and compulsory secondary education within the minimum possible period" (p.18). Moreover, the vigorous education sector can determine the country's progress and socio-economic development necessitates. Therefore, education is the path to silver roads of prosperity and the removal of dark shadows of poverty.

The governance of the education sector is under the Federal Ministry of Education and the Provincial governments; these offices authorize and facilitate curriculum development and accreditation process. The education system of Pakistan segregates into three principal categories that comprise public, private, and madrasa education systems (Looney, 2008). Hence, the language of instruction, quality of textbooks, curriculum, and management styles draw rigid lines amid these education systems. These further furcated into subtypes, mainly due to diverse curriculums, quality of textbooks, exam systems used in the schools, and the language of instructions used by teachers.

The public education system bifurcates into five levels, primary (1-5), middle (6-8), high school (class 9-10 or Secondary School Certificate), HSSC (class 11-12 or Higher Secondary School Certificate), and University (Undergraduate, graduate, and post-graduate or doctoral degree programs). Besides, the private education system split into six levels, preschool (from age 3-5), primary (class 1-5), middle (6-8), high school (9-10 or Secondary School Certificate), HSSC (class 11-12 or Higher Secondary School Certificate), the GCE (General Certificate of Education) system that replaces the SSC/HSC with O and A levels, administered by external British Examination Board of Cambridge and University (Undergraduate, graduate, and post-graduate or doctoral degree programs)( Asian Development Bank, 2019). Yet the madrasas system is also providing elementary Islamic education at the secondary level of education in the country (Bashir \& Shoaib, 2019). Mostly madrasas have an Islamic curriculum and the management system operates by these Madrasas, without the interference of federal and provincial level government. Madrasa is an Islamic educational institute that offers the teaching of the Quran, hadith (the sayings of Prophet Muhammad) jurisprudence (fiqh), and Islamic law (Blanchard, 2007). More than12000 registered madrasas in Pakistan are offering Islamic education (Bashir \& Shoaib, 2019). Furthermore, for the educational obligation the potential participation, strong framework, and cooperation is the vital agenda of the country (National Education policy, 2018).

The disparity in the language of instruction among different school types is also the big chaos Urdu, English, and Madrasas system of schools. The medium of schools also presents diverse classes of society. Mostly in public schools, the medium of instruction is Urdu and in private schools, the medium of instruction is English; in Madrasas, the local languages(Urdu) and Arabic language are used (Asif et al., 2020). As Bizenjo (2020) claimed privatization of education in Pakistan is the ultimate result of the inadequacy of the education system; consequently, private schools are providing the quality of education as compared to public schools with a high amount of fees and only led class parents can afford it. As a developing country; the majority is a low-income population that caters to the public school where the 
quality of education is not meeting the standards of quality education. Quality of education that represents the quality of teaching at different school systems also creates a hurdle to achieve the acquired standards of education in the country (Barber and Mourshed, 2009).

Despite, the education sector is undergoing the massive challenges wherein the decline education quality, access and large out of school children, and unchanging education system, and lacking competency and skill abilities of teachers (NEP, 2018); the government endeavors to address although still, many issues need to address. According to the Global Education Monitoring Report UNESCO 2017/18, Pakistan is also in the E9 countries list where the world's highest out of school population. Pakistan as a developing nation, with a $203,517,776$ population, is dealing with contradictory economic and political challenges. Besides, the country faces a massive number increasing Out of School Children (OOSC) that is almost 22.5 Million (Pakistan Education Statistics, 2017) Primary net enrolment rates (NER) remained the same; yet, gender discrepancies, economic and geographic disparity has been remained prominent at the province levels. According to the static, the most disadvantaged parts of the country are Balochistan and FATA where this number is alarming (ADB, 2019). Yet, deterioration enablers of education sector, with the instability of economic and social degeneration. Contrary, the $2 \%$ gross national budget allocation is the lower percentage than comparable developing countries (ADB, 2019); hence the wobbly structure of education with less financial support seems to fail to raise the social-economic and political development of the country. Besides, Pakistan adopted more than 25 educational policies; to underpin the educational phenomena but still lacking the adequate standards which country needs for economic and social development.

The key calamity of the education system is an insufficiency of financial support, lack of national policy implementation strategies, flawed examination system, lack of adequate physical facilities, no scale for quality teaching, lack of teaching training, a significant figure of out of school children, early dropouts from school, political instability, lack of quality curriculum, lack of uniform curriculum corruption, terrorism, lack of educational leadership and management skills, limited facilities for career counseling, lack of technical and vocational training, the diverse medium of school setups and lack of research opportunities are the challenges for the country (Memon, 2007; Rehman \& Khan, 2011).

Moreover, China's magnificent expansion and progressions in the latest research and development and the invention are remarkable and stunning; globally in 2008, China surpassed Japan in R\&D expenditures; and the scientific research productivity of China is also increasing (Breznitz \& Murphree, 2013). Thus, the global rise of China as 'Asian Dragon' is the achievement of educational and technological standards of the China education system that is producing competitive manpower according to national and international market demand. Although, our intended SWOT analysis to analyze the CPEC indirect influence on the Pakistan education sector. To see the integration of country shortcomings of the education system; and how the CPEC can bring the internationalization of the education system in the country. 


\section{China-Pakistan Economic Corridor}

China-Pakistan Economic Corridor (CPEC) is a part of the Belt and Road initiative that is the reawakening of ancient Silk Road objectives; Belt and Road initiative is an economic web that integrates China with Europe, Asia, and Africa. Belt and Road initiative will provide an economic boost to China's economy and as well as all other interlinked countries (Hali, 2018). The frameworks of the project comprise two parts, "The Maritime Silk Road" (MSR) and the "Silk Road Economic Belt" (SREB). That connected almost 65 countries all around the world through these routes. ${ }^{23}$ MSR cover the route from Guangxi Zhuang Autonomous Region and Yunnan province, and connected through various seaports in the South China Sea, the Andaman Sea, Bay of Bengal, the Arabian Sea, the Persian Gulf and it will terminate at the Baltic Sea connecting 65 countries all around the region linking Europe, Central Asia, Africa, and beyond. ${ }^{1}$ OBOR covers the land routes that include China-Mongolia-Russia Land Corridor, the China-India-Bangladesh-Myanmar Corridor, China Central-Asia West Asia Corridor. ${ }^{6}$ One Belt One Road is the evidence of Chinese leadership planning for molding their economic growth towards globalization, which gives more advancement to their infrastructure development.

The "China-Pakistan Economic Corridor" (CPEC) is a step towards economic capitalization and globalization for Pakistan, a new era of regional peace, as a whole economic development and growth for the entire region. ${ }^{2}$ Pakistan and China signed the CPEC agreement in November 2014, a properly Memorandum of Understanding (MOU) the contract of mutual ties between both countries. CPEC connecting China's market with the Middle East, Africa, and Asia, and Xinjiang (China) with Gwadar port in Baluchistan (Pakistan) has significant strategic and economic importance for China and Pakistan. ${ }^{3} \mathrm{CPEC}$ Gwadar port is locus is industrial, infrastructure, communication, and energy zone. ${ }^{4}$ In these developmental projects, China invests the US \$ 46 billion. ${ }^{5}$ Ahsan Iqbal (Former Minister of Planning\& Development) of Pakistan said that "CPEC is not the name of a single route or alignment, it is a complete package of cooperative initiatives and projects about regional connectivity, energy cooperation, industry and industrial parks, agricultural development, and poverty alleviation which will result in thousands of new ventures and millions of jobs in every part of Pakistan." 7

$\mathrm{CPEC}$ is one of the unique corridors which provide a massive range of access in its strategies that combine world trades and economic development. On the other hand, it brings the wellestablished and latest technology to the countries that raise different opportunities to strengthen their weak points. Moreover, the web of Belt and Road is connecting billions of people all around the region, an opportunity to exchange trades, communication, and culture. ${ }^{8}$ According to Chinese President Xi Jinping; "The CPEC is located where the Silk Road Economic Belt and the 21st Century Maritime Silk Road meet." As stated by Pakistan's Ambassador to China Masood Khalid said: "The CPEC will act as a bridge which connects China with the other world through the Arabian Sea."10 


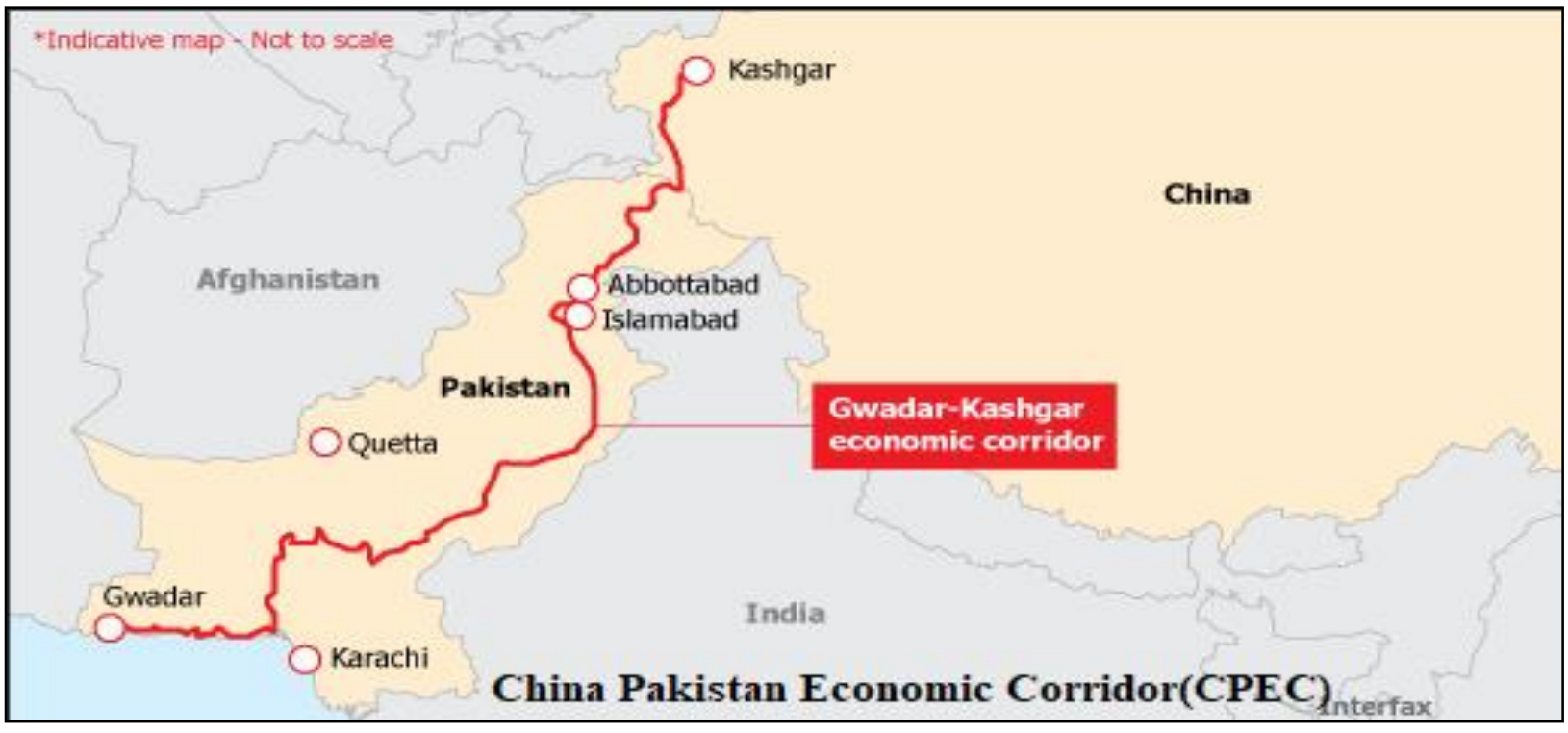

Source: China Pakistan Economic Corridor ${ }^{11}$

As Asian Development Bank,2019 claimed as "CPEC will act as an economic hub from which different regional stakeholderswill benefit through the utilization of their economic resources. This route will help in matching the supply and demand sides of markets." 12 According to the General Agreement on Tariffs and Trade Article XXIV of the World Trade Organization (WTO), Pakistan and China are also the members of their trade policies. In term of WTO, the member countries can infiltrate in territorial agreements, as a result of contradictoryeconomic and structural dissimilarities, it is crucial to see the form comparative theory aspect. For the relative advantages, the countries have to focus on their weak areas to learn and improve these areas through this trade initiative (Shabir and Kazmi, 2007). Apart from distinction features of ideologies and obvious differences China and Pakistan havelonglasting friendly connections, which can help improve the economic system of Pakistan. (Muhammad et al., 2015).

\section{Methodology and Procedures}

The study employs a SWOTanalysis, examining the internal strengths and weaknesses and external opportunities and threats totheeducation system of Pakistan through CPEC. Through SWOT, the study observes the potential impact of CPEC on the Educational sector of Pakistan.

\section{Results and Discussion}

A SWOT Analysis ofthe Pakistan Education System, the impact from China Pakistan Economic Corridor (CPEC):

\section{Strengths}

1. Higher education is an essential tool for beneficial interaction among nations; ties mutual understanding every field of endeavour and equip the next generation of leaders, to rise 
with global challenges; higher education is a resonant phenomenon(Cohen et al., 2013; Egron-Polak \& Hudson, 2014). The long way of this successful friendship among the countries is the evidence that the CPEC Initiative ties the roots of the relationship stronger. The effective educational contribution among the countries increasing mutual understanding. Better mutual understanding provides a foundation of trust upon which the nextpolicies and agreements can establish.

2. "With almost 19,000 students from Pakistan studying in China last year, the South Asian country has risen from the ninth-largest source of China's international students to the fourth." ${ }^{\prime 3}$ According to the Chinese Ministry of Education; "more than 317,200students from 64 countries along the Belt and Road Initiative were studying in China last year, in 2017" ${ }^{14}$ ChineseGovernmentinitiative broadens the horizon of internationalization in the education sector too; Internationalization embraces diplomatic, economical, and cultural sectors along with the quality of graduate students learning outcomes (Ardakani et al., 2011), that unlocked the prosperity for the Pakistan educationsectorwithtechnology, research, culture, and knowledge exchanged, that is remarkable.

3. Large-scale technology exchange is the key objective of the CPEC Initiative, but it hasan impact on educational technologies too, Chinese Government is catering to a large range of students in their well-known world ranking universities (Yang, 2015); is the evidence that it advances the developing country education sector too.

4. No one can deny this fact that Pakistan terms with China always strengthen the pretensions of the Pakistani Government, scholarshipawardees' doctoral and master students' when returning to the country it will facilitate the higher education sector demands, which the country is lacking.However these, doctoral students are catering to the need of the country at specifically in territory education.

5. China's dream of revitalizing the 'Silk Road', now emergent with new trade routes in the world, for Pakistan CPEC, has great significance from Gwadar (deep seaport, Pakistan) to Kashgar (China) strengthen the geographic importance of Pakistan and enhance the logistical importance in the region, Belt and Road is the economic hub for South Asia and 'Educational Hub for Pakistan'. Strengthen the Geographic location of Pakistan and as well as the economic and educational sectors too.

6. Pakistan is a developing country where the main earning source of the population is agriculture, low-income constraints. The country is not financially stable to organize employment and jobs for the youngand pay labor the handsome amount. CPEC initiative helps to increase the growth of the economy, that ultimately impacts the growth of the society and as well as on the national level too. CPEC is a complete package of economic progress of Pakistan. ${ }^{15}$

7. Socio-Political, Ethical, and Cultural Development, besides the involvement of more than 60 countries, CPEC got a new participant to this game-changer project i.e. Saudi Arabia. ${ }^{16}$

8. The main aim of Pakistan's foreign policy is to keep a valuable and fair relationship with its neighboring countries. In Pakistan's foreign policy objectives, China has been an essential part. Since 1951, these ties of friendship is kept growing and the Pakistani government also provides great support to CPEC initiatives (Abid, 2016). 


\section{Weaknesses:}

1. Besides, CPEC strengthens the devolving economy of Pakistan but at the same,Pakistan's economy relies more on China because both countries are not equal strengthens. ${ }^{17}$

2. International Propaganda against CPEC, No one can deny the significance of CPEC for Pakistan's economy, the initiative has been antagonistic by internationally, and misrepresentation of facts that is not the objective of the Chinese Government. International propaganda against CPEC is no more a shock to us, as anti-Pak forces cannot bear the development of Pakistan.

3. The massive engineering challenges of CPEC construction as indicated by Miller (2019 p.175) are the big barriers for China.

4. Global Anti-Pakistani forces provoke the sovereignty of Pak and CPEC by blaming the intentions of the current government towards the progress of Pakistan and give the impression through media that Prime Minister Imran's governmentis opposing the CPEC. As the interview of Prime Minister Imran's appointed Adviser Razzak Dawood has been misquoted in 'Financial Times' over the terms of the deal regarding the CPEC at a time when the Chinese Foreign Minister was on three days' visit to Pakistan. He was misquoted that the new government would review the multi-billion dollars' corridor.

5. Local anti-CPC political parties also raised serious objections to CPEC. Even PTI and JUI (F) showed reluctant behaviour towards CPEC and the objection was raised on the account of equal opportunities to all the provinces. ${ }^{18}$

6. Beijing to Balochistan, location vise Balochistan has significant importance in CPEC that is linking the deep-water port of Gwadar with Kashgar China. The peace of Balochistan was targeted by Baloch insurgents, who oppose Balochistan, especially Gwadar development, numerous attempts to make the project delay comprising strikes on gas pipelines, trains, and Chinese engineers. These anti-Pakistani forces do not want to see the development of the province which weighs the demographic value of Balochistan. ${ }^{19}$

7. The mega project of CPEC double the economy's progress but at the same time raised the serious issues of taxes. Although the country is facing energy constraints and heavy electricity prices. The CPEC energy projects in Pakistan decrease energy issues, which is a depressingly effect on project manufacture alignments in Pakistan. ${ }^{20}$

\section{Opportunities:}

1. Financial Barriers remains the largest encumbrance in the development of Pakistan. The country's classified into the $3^{\text {rd }}$ World countries list (ADB, 2019) with a low level of literacy and development. $68 \%$ population depending on the agriculturalsector, $40 \%$ are below the average line of poverty and unable to feed their families cannot think of sending children to school as the result the development stops and dense poverty lines become thicker. Besides, population growth is another issue. CPEC is an economiccorridor that boosts the economic development of the country with $\$ 274$ billion GDP by over $15 \% .^{21}$ Getting rid of financial barriers that causehindrance in the establishment of new infrastructure fortheeducation sector. 
2. The first and foremost education challenge, which the ministry of Pakistan is facing, is to handle a bigfigure of 'Out of School Children' (OOSC); ensuring that enrolled children completes their education. The majority of these children are from rural parts of the country, like Balochistan and FATA Bhawalpur (Punjab), Tando Mohammad Khan (Sindh) and Harnai (Balochistan), and Kohistan( NEP,2018). The reason behind this challenge is the low income of rural area population and child-labor. According to a UNICEF report in Pakistan, $17.6 \%$ of children are supporting their families. CPEC initiative supports the Government's financial programs and with plenty of funds allows the Government to pay attention to this serious education demand. It also reduces the 'Child Labour' dilemma of the country.

3. China has the biggest 'State-Run Education System' in the world (Chinese Ministry of Education, 2019). "China has a massive number of higher education institutions and universities, where Pakistan needs to improve his education sector demands and quality of education with a betterfoundation; due to limited resources. Thus the country is unable to extend the educational facilities to the children. CPEC is the strategic door that can build better cooperation in the field of Education. Exchange faculty programs, exchange student programs, promotion of high quality of research within Pakistan with the collaboration of China to promote research and quality of education with global standards.

4. Higher education institutes and universities are lacking the skills education, lack of mechanisms; outdated curricula; competency-based training and assessments, the weak linkage between industry and university. Out of 140 economies countries list, Pakistan ranks $125^{\text {th }}$ on the Global Competitiveness Index 2018. ${ }^{22}$; leads that country is lacking the skills and capabilities to meet the demand of the market. In the field of engineering China is offering 631 engineering disciplines, while Pakistan is offering 30 engineering disciplines. China has world-class engineering universities with a high impact of research and technology education, being a CPEC member Pakistan must have strengthened the collaboration with China research education (Channa, 2018).

5. Globalization and collaboration around the globe are buzzwords; each country is planning to raise global links and policies. These education exchange programs also have animpact; people to people education enriches our educational domains and thinking skills. CPEC is a mega project which is connecting 64 countries and providing massive opportunities forcollaboration with a large number of companies and industries. Although, it enhances the chances of cross-cultural exchange with diverse cultures and languages. Trade and education exchange programs allowmaking new friendships and relationships.

6. Education can fetch the objectives of cultural and social harmony. Exchange of a competent understanding of Chinese foreign policy goals allows Pakistan to broaden their participation in global issues (Foreign Affairs Government of Pakistan, 2015). Equalization of educational opportunity for Pakistan, as a developing nation; on the samecircumstancebeing the main part of CPEC Pakistan must association with China in the education sector. 
7. Widen theenvision of policymakers of Pakistan, exchange of policy matters to meet the demands of globalization, and which competency the curriculum has to adapt by learning the Chinese curriculum reforms and implementation strategies. Competency-based curriculum for schools according to market demand; which enhances cultural harmony with the modern world.

8. CPEC provides an opportunity for Pakistan to interlink physically with the biggest economy of the world. The CPEC project is a game-changer for Pakistan as it is expected to concentrate on the shortcoming of the country, and Pakistan gets the chance to learn and adapt educational strategies and educational policy implementation plans from China, which is one of the essential drops back of Pakistan education sector.

9. Female education; the studies claimed that the female students' ratio is increasing towards the higher education sector and these educational exchange programs are also providing 'more flexible facilities' for female and as well as the border the horizon of a cultural exchange program which also leads the strengthen of female education and eliminate the non-availability of female teachers' problem from the country.

10. According to UNESCO, educational expenditure for developing countries in the education sector should be $4 \%$ of G.N.P; while Pakistan is spending $2.2 \%$ of G.N.P on the education sector. Since the 1990s the expenditure on the education sector is declined. The initiative of CPEC also facilitates the Ministry to allocate more funds to the education sector to enhance the physical and Instructional materials. Therefore, with the growth of the economy, ultimately the economy develops an impact on the education sector and the government can invest more in deficient areas like buildings and furniture, laboratories, equipment, textbooks, and sports.

11. A shortcoming of Educational institutions' curriculum lacks in progress, performance, and academic research. Is the main hindrance to the expansion of knowledge in the country?Hence, the new economic revival also impacts the need forrevision of the curricula at each level to make it meaningful and responsive to the needs of the society.

12. Peace and prosperity in Province (Balochistan), it also creates the air of prosperity at the province level that was lacking the latest facilities of technology and the majority ofofyoungsters are facing unemployment. The ratio of economic development in that province was low which also get beneficent from CPEC. ${ }^{24}$

\section{Threats:}

1. The language barrier, Urdu and English are the two most commonly used languages of the country; Urdu as the national language and English is the official language for communication, the impact of CPEC get influence by language that creates the hurdles. Hence, the implementation of these educational initiatives in the country.

2. Cultural barriers, both countries have different cultural and historical backgrounds that may cause resistance to accepting each other.

3. Old System may resist the new system after the independence; the education system was under the influenced adopted from the British that they left over. Unfortunately, the government paid less important to deal with the country's education need that was carried 
in the same way, so that the old system which the nation used too may resist against the new one. Change has to face the resistance because it takes time to understand and adapt it, to the people also resistant to accepting it.

4. Resistance from religious groups in the country, mostly in rural areas school got the negative influences of religious parties; which also sometimes cause the hurdles for female education and as well as for education as a whole ( Miller, 2019).

5. Terrorism, the promotion of literacy operation also gets affected by the War against terrorism. The terrorist attacks on schools, colleges, and students; blown up several educational institutions' in Balochistan, Khyber Pakhtunkhwa (KPK), and Federally Administered Tribal Areas (FATA). Pakistan's engagement in the war against terrorism also affected the education system. This may have to contribute not as much as other factors, but this remains a major factor.

6. Resistance from the private education system; the education system of Pakistan have different categories like public and private school systems; public school are under the ministry of education. That are lacking educational facilities and effective learning environment for the students on another side private school run by a different private organization, providing a high quality of education, in return of heavy fees; when public school upgrades their structure and system of education these private organizations do resist this change for their self-benefits.

\section{Conclusion and Suggestion}

CPEC is a massive project which has great potential for Pakistan in different areas. Pakistan has adapted valuable policies for economic, energy, and political development. Hence, the country needs to understand the full potential of this project; that is, this project is not only limited to just an economic or defensive perspective but a lot can be gained from cooperation in different areas. The Chinese education system is one of the best in the world, producing a competitive workforce for its regional and international demand. Through the SWOT framework, the study found out that CPEC has more opportunities in the education sector as compared to threats. Through CPEC, Pakistan has an opportunity to benefit from the experiences of China in the education sector and can adopt different modern technologies which China is using right now in the education sector especially in the field of engineering, technology, and vocational and technical training skills educational programs which will also determine the unemployment challenge of the country. Moreover, the existing shortcomings of the education system can be addressed. Thus, the concerned authorities in the country should examine the massive influence of CPEC and how it can boost the nation towards prosperity, although several challenges are ahead. Therefore, there is a need to formulate adequate policies and take the measurements to use this opportunity effectively, and International propaganda can be denied by mutual understanding and commitment that can lead CPEC towards success. 


\section{Conflict of Interest}

The authors of the article declare no conflict of interest.

\section{Funding}

This research study was not funded by any institution. The authors conducted the study on their own expenses.

Notes:

1. Dr.Hasan Askari Rizvi, "The China-Pakistan Economic Corridor: Regional Cooperation and Socio-Economic Development", Institute of Strategic Studies Islamabad (ISSI) Journal, Vol. 34 and 35, No. 4 and 1, (Winter 2014 and Summer 2015): 10, (accessed April 5, 2016), http://issi.org.pk/wpcontent/uploads/2015/12/Hasan-Askari-Rizvi_3435_SS_41_20142015.pdf.

2. https://worldview.stratfor.com/article/china-one-belt-one-road-no-plan

3. https://timesofislamabad.com/18-May-2018/cpec-opportunities-and-challenges-forpakistan

4. Asia Development Bank,2019.

5. https://www.cpicglobal.com/pakistan-overview/cpec/

6. https://worldview.stratfor.com/article/china-one-belt-one-road-no-plan

7. Dr. Moonis Ahmar, "Strategic Meaning of the China-Pakistan Economic Corridor", p. 42 , http://issi.org.pk/wp-content/uploads/2015/12/MoonisAhmar_3435_SS_41_20142015.pdf.

8. Muhammad Saqib Irshad, Qi Xin, and Hamza Arshad, "One Belt and One Road: Does China-Pakistan Economic Corridor Benefit for Pakistan's Economy”, Journal of Economics and Sustainable Development, Vol.6, No. 24, (2015): 203.

9. Dr. Hasan Askari Rizvi, "The China-Pakistan Economic Corridor: Regional Cooperation and Socio-Economic Development", Institute of Strategic Studies Islamabad (ISSI) Journal, Vol. 34 and 35, No. 4 and 1, (Winter 2014 and Summer 2015): 10, (accessed April 5, 2016), http://issi.org.pk/wpcontent/uploads/2015/12/Hasan-Askari-Rizvi_3435_SS_41_20142015.pdf.

10. One Belt One Road Provides New Drive for Regional Sustainable Development", People's Daily, April 8, 2016, (accessed April 11, 2016), http://en.people.cn/n3/2016/0408/c90000-9041876.html.

11. www.lahistoriaconmapas.com/atlas/country-map03/economic-corridor-pak-chinamap.htm

12. Ibid, p. 39.

13. the DAWN https://www.dawn.com/news/1317973 "With almost 19,000 students from Pakistan studying in China last year, the South Asian country has risen from the ninth-largest source of China's international students to the fourth.”en.moe.gov.cn/News/Top_News/201804/t20180403_332258.html 
14. Muhammad, S.I., X. Qi, and A. Hamza, 2015. One belt one road: Dose ChinaPakistan economic corridor benefit for Pakistan's economy? Journal of Economics and Sustainable Developments, 6(24): 200-207.

15. "Is China Incompatible With Democracy?," Caucus Brief, Washington DC: State Government of Virginia, 2014, http://forbes.house.gov/news/ document single.aspx? DocumentID=397844

16. www.brecorder.com/taxation/181:pakistan/ 1251063: energy-projects-under-CPEC:china-concerned-at-tax power- tariff -security-issues

17. Falak, Jawad. CPEC: Internal Significance and Challengeswww.stratagem.pk/strategic-pulse/cpecinteranl-significance-andchallenges

18. www.ipripak.org/cpec-and-the-baluchistanfactor/\#sthash.05TR0DCE.dpuf

19. Falak, Jawad. CPEC: Internal Significance and Challenges www.stratagem.pk/strategic-pulse/cpecinteranl-significance-and-challenges

20. www.forpakistan.org/fpdata/costs-and-benefits-of-cpec

21. Acute skills shortages are perceived by firms in the construction, manufacturing, and education sectors (Employer Survey 2013).

22. www.economist.com/news/asia/21653657-conflictbalochistan-must-be-resolvedtrade-corridor-betweenpakistan-and-china-bring.

23. Although composed of two separate policies, the Silk Road Economic Belt and the $21^{\text {st }}$ Century Maritime Silk Road, we will refer to "One Belt, One Road" as a single initiative throughout the article. Michael Swaine, "Chinese Views and Commentary on Periphery Diplomacy," China Leadership Monitor, no. 44 (Summer 2014), http://www.hoover.org/research/chinese-views-and-commentary-peripherydiplomacy.

\section{References}

Abid, M., \& Ashfaq, A. (2015). CPEC: Challenges and opportunities for Pakistan. Journal of Pakistan Vision, 16(2), 142-169.

ADB (Asian Development Bank), 2019, School Education in Pakistan: A sector Assessment, TCS190039, DOI: http://dx.doi.org/10.22617/TCS190039.

Albert, E. (2018). China's big bet on soft power. Council on foreign relations, 9. Retrieved from Council on Foreign Relations: https://www.cfr.org/backgrounder/chinas-big-betsoft-power

Ardakani, F. B., Yarmohammadian, M. H., Abari, A. A. F., \& Fathi, K. (2011). Internationalization of higher education systems. Procedia - Social and Behavioral Sciences, 15, 1690-1695. doi:10.1016/j.sbspro.2011.03.353.

Channa, A. S., Amin, F. R., Liu, G., \& Chen, C. (2018). The Engineering Education in China, Compared to Pakistan, Europe, and the USA, in Prospects of One Belt, One Road. Higher Education Studies, 8(3), 15-26. 
Cohen, A., Yemini, M., Sadeh, E (2013). "Web-based analysis of Internationalization in Israeli teaching colleges", Journal of Studies in Internationalization Education,.Doi: $10.1177 / 1028315313479131$.

Breznitz, D., \& Murphree, M. (2013). The rise of China in technology standards: New norms in old institutions. Prepared for the US-China Economic and Security Review Commission, 16.

Egron-Polak, E., \& Hudson, R. (2014). Internationalization of higher education: Growing expectations, fundamental values. IAU 4th global survey. Paris: UNESCO International Association of Universities.

European Commission (EC) (2018) EuropeanInnovation Scoreboard 2018. Available online at:https://ec.europa.eu/growth/industry/innovation/ facts-figures/scoreboards_en [Accessed 15 July 2018].

Memon, G. R. (2007). Education in Pakistan: The key issues, problems and the new challenges. Journal of Management and Social Sciences, 3(1), 47-55.

Khan, M. (2015). Analysis: Trade through Land Routes. The Dawn.https://www.dawn.com/news/1202356

Maher, M. Y., Zakir, H., \& Nisar, A. (2014). Economic Evaluation of Foreign Direct Investment in Pakistan. Pakistan Economic and Social Review, 46, 37-56.

Mateen, I. (2015). CPEC: Economic Corridor in Focus as Pakistan, China Sign 51 MOUs. The Dawn. http://www.dawn.com/news/1177109

Bashir, M., \& Ul-Haq, S. (2019). Why madrassah education reforms don't work in Pakistan. Third World Quarterly, 40(3), 595-611.

Irshad, M. S. (2015). One belt and one road: dose China-Pakistan economic corridor benefit for Pakistan's economy?. Journal of Economics and Sustainable Development, 6(24).

Irshad, M. S. (2015). Pakistan-China free trade agreement (PCFTA) treaty model: Capability, prospects and disputes. Academic Research International, 6(3).

Pakistan Education Statistics (2016/17)

Pakistan National Education Policy 2018

Rehman H. and Khan N. (2011). "The flaws in Pakistan's Education System", Abasyn Journal of Social Sciences, vol. 4. No.1

Asif, S., Afzal, I., \& Bashir, R. (2020). An Analysis of Medium of Instruction Policies in the Education System of Pakistan with Specific Reference to English Medium Education. sjesr, 3(2), 370-382.

Shabir, S., \& Kazmi, R. (2007). Economic effects of the recently signed Pak-China free trade agreement. Lahore Journal of Economics, 12(Special Edition), 174-202.

Hali, S.(2018). One Belt and One Road: Impact on China-Pakistan Economic Corridor. Strategies in Trauma and Limb Reconstruction, 30.

Shapiee, R., \& Idrees, R. Q. (2017). China Pakistan Economic Corridor (CPEC); Most Valuable Dream for Pakistan through Economic Integration in the Region but May Not Become True without Upgradation of Physical Infrastructure and Legal System. Beijing L. Rev., 8, 481.

Bizenjo, S. (2020). Education in Pakistan: Are low-cost private schools closing the gender gap?. International Journal of Educational Development, 77, 102209. 
Barber, M., \& Mourshed, M. (2009). Shaping the future: How good education systems can become great in the decade ahead.: Report on the International education roundtable, Singapore, 7 July.

Miller, T. (2019). China's Asian dream: Empire building along the new silk road. Zed Books Ltd..

Vickerman, R. (2002). Restructuring of transportation networks. In Regional development reconsidered (pp. 148-159). Springer, Berlin, Heidelberg.

Kirby, W., \& Van der Wende, M. (2019). The New Silk Road: implications for higher education in China and the West?. Cambridge Journal of Regions, Economy and Society, 12(1), 127-144.

Yang, R. (2015). Reassessing China's higher education development: A focus on academic culture. Asia Pacific Education Review, 16(4), 527-535.

Zafar, H. (2014). The corridor of hope. Daily Times, 25. http://www.dailytimes.com.pk/ business/25-Jul-2015/the-corridor-of-hope. 